\title{
Pengaruh Promosi Kesehatan terhadap Perilaku Pencegahan dan Pengobatan Tuberkulosis Paru di Puskesmas Batu Tunggal Labuhan Batu Utara Kecamatan Na Lx/X Kabupaten Labuhanbatu Utara Tahun 2021
}

\author{
Zuidah \\ Program Studi Keperawatan, Universitas Haji Sumatera Utara
}

\section{Info Artikel}

Article history:

Diterima 11-06-2021

Revisi 27-06-2021

Disetujui 13-07-2021

\section{Kata kunci:}

Promosi Kesehatan, Perilaku pencegahan, Pengobatan.

\begin{abstract}
A B S T R A K
Tuberkulosis (TB) merupakann penyakit menular langsung yang disebabkan oleh kuman TBC (Mycobacterium tuberculosis), kurangnya prilaku pasien dalam pencegah tuberkulosis membuat pengobatan yang tidak tuntas sehingga pasien TB akan harus melakukan poengotan berulang, tujuan penelitian ini Untuk mengetahui apakah ada Pengaruh Promosi Kesehatan Terhadap Perilaku Pencegahan dan Pengobatan Tuberkulosis Paru Di Puskesmas Batu Tunggal Labuhan Batu Utara Kecamatan NA IX/X Kabupaten Labuhanbatu Utara Tahun 2021. Penelitian ini menggunakan jenis penelitian kuantitatif, dengan desain crosssectional, Desain penelitian ini menggunakan desain crosssectional, Populasi dalam penelitian ini adalah pasien TB Paru yang telah dikumpulkan sebanyak 80 pasien TB Paru, Jadi jumlah sampel dalam penelitian ini adalah Teknik Purposive Sampling Jadi jumlah sampel dalam penelitian ini adalah sebanyak 44, dengan teknik penelitian menggunakan Uji Wilcoxon digunakan untuk melihat pengaruh antara dua variabel dengan derajat kepercayaan $95 \%$. Hasil penelitian ini terdapat pengaruh yang signifikan antara promosi kesehatan terhadap perilaku pencegahan Tuberkulosis Paru, terdapat pengaruh yang signifikan antara promosi kesehatan terhadap pengoatan Tuberkulosis Paru di Puskesmas Batu Tunggal Labuhan Batu Utara Kecamatan NA 1X/X Kabupaten Labuhanbatu Utara Tahun 2021. Saran bagi Pemerintah setempat khususnya Dinas Kesehatan Kabupaten Labuhanbatu Utara agar dapat merancang strategi promosi kesehatan yang lebih baik dalam penurunan kasus TB Paru melalui program pencegahan TB Paru.
\end{abstract}

\section{Koresponden Penulis:}

Zuidah,

Program Studi Keperawatan, Universitas Haji Sumatera Utara,

Jl. Rumah Sakit H., Medan Estate, Kec. Percut Sei Tuan, Kabupaten Deli Serdang, Sumatera Utara 20371.

Email: zuidah66@gmail.com

\section{PENDAHULUAN}

Tuberkulosis (TB) merupakann penyakit menular langsung yang disebabkan oleh kuman TBC (Mycobacterium tuberculosis), sebagian besar kuman TBC menyerang paru. TB Paru yang disebabkan oleh Mycobacterium tuberculosis merupakan penyakit kronis (menahun) yang telah lama dikenal oleh masyarakat luas dan ditakuti karena menular. Penyakit ini menjadi tidak terkendali pada sebagian besar dunia, dan salah satu penyebab utama kematian di Indonesia serta negara-negara berkembang lainnya (Depkes, 2017).

Berdasarkan Global Report Work Healty Organisasion pada tahun 2015 menyatakan jumlah penderita tuberkulosis paru di dunia sebanyak 14,4 juta kasus. Wilayah Asia Tenggara menanggung bagian yang terberat dari beban tuberkulosis paru global yakni sekitar $38 \%$ dari kasus tuberkulosis paru dunia. Penyakit tuberkulosis paru merupakan penyebab kematian ketiga terbesar setelah penyakit kardiovaskuler dan penyakit saluran pernapasan dan merupakan nomor satu terbesar penyebab kematian dalam kelompok penyakit infeksi 
Di Indonesia, pada tahun 2017 prevalensi penderita tuberkulosis paru sebesar 102 per 100.000 penduduk atau sekitar 236.029 kasus tuberkulosis paru dengan BTA positif. Menurut Depkes (2018), TB merupakan salah satu masalah kesehatan penting di Indonesia. Selain itu, Indonesia menduduki peringkat ke-3 negara dengan jumlah penderita TB terbanyak di dunia setelah India dan China. Jumlah penderita TB di Indonesia adalah sekitar 5,8 \% dari total jumlah penderita TB dunia. Di Indonesia, diperkirakan setiap tahun terdapat 528.000 kasus TB baru dengan kematian sekitar 91.000 orang. Angka prevalensi TB di Indonesia pada tahun 2019 adalah 100 per 100.000 penduduk dan TB terjadi pada lebih dari $70 \%$ usia produktif. Dalam keadaan itu kerugian ekonomi akibat TB juga cukup besar (Depkes, 2018).

Aspek penggunaan obat, diketahui cakupan penggunaan OAT (Obat Anti Tuberkulosis) berupa FDC (Fixed Dose Combination) dan Kombipak sebesar 83,2 persen. Lima provinsi dengan persentase lebih dari $90 \%$ dalam memanfaatkan OAT Kombipak/FDC adalah Sumatera Selatan (95,3\%), Sumatera Utara $(95,0 \%)$, Kepulauan Riau (91,5\%), Kalimantan Timur (91,5\%), dan Kalimantan Selatan $(91,3 \%)$. Persentase penderita TB yang telah menyelesaikan pengobatan OAT sebanyak 59,0 \%, sebanyak 19,3\% berobat tidak lengkap ( $<5$ bulan) dan tidak minum obat 2,6 \%. Sedangkan pemeriksaan mikroskopis, diketahui Crude Point Prevalence yang berasal dari pemeriksaan mikroskopis dahak jika paling sedikit satu slide positif sebesar 0,704 \% (704 per 100.000 penduduk) sedangkan Point Prevalence dengan dua slide positif sebanyak 132 kasus (289 per 100.000 penduduk), sedangkan kasus BTA positif pada penduduk dengan satu slide positif sebesar 189 kasus (415 per 100.000 penduduk).

Profil Kesehatan Provinsi Sumatera Utara tahun 2012, diketahui penemuan kasus baru TB Paru (+) sebanyak 14.302 jiwa (68,86\%), dan dari 33 Kabupaten/Kota tertinggi adalah kota Gunung Sitoli $(163,41 \%)$, dan terendah Kabupaten Karo yaitu 39,75\%, dan angka kesembuhan sebesar 75,32\%. Angka tersebut menunjukkan kasus TB paru di Provinsi Sumatera Utara masih tinggi. Upaya strategis yang dapat dilakukan adalah melalui upaya pencegahan terhadap terjadinya TB paru pada masyarakat, upaya tersebut dapat dilakukan melalui pendidikan dan promosi kesehatan, karena faktor yang dinilai berkontribusi terhadap kejadian TB paru adalah faktor perilaku kesehatan individu (Green, 2015).

Salah satu determinan terhadap terjadinya masalah kesehatan adalah faktor perilaku kesehatan meliputi pengetahuan, sikap dan tindakan. Upaya peningkatan perilaku kesehatan dapat dilakukan dengan pendidikan dan promosi kesehatan sesuai dengan konsep Green (2015), yang menjelaskan bahwa perilaku kesehatan dipengaruhi oleh multi faktor, baik faktor pendukung seperti karakteristik individu, faktor penguat yaitu ketersediaan sarana kesehatan, dan faktor pemungkin seperti dukungan petugas kesehatan (Green, 2015).

Promosi kesehatan (health promotion) sebagai suatu proses untuk meningkatkan kemampuan masyarakat dalam memelihara dan meningkatkan kesehatannya. Peningkatan kesehatan yang dimaksud adalah pencapaian derajat kesehatan yang sempurna, yang meliputi kesehatan fisik, mental, dan sosial termasuk kesehatan lingkungan, dan setiap individu, keluarga dan kelompok masyarakat harus mampu meningkatkan derajat kesehatannya (Green, 2015).

Upaya promosi kesehatan di masyarakat dapat dilakukan dengan media promosi kesehatan seperti penyuluhan kesehatan pada masyarakat, media leaflet dan brosur, maupun secara tehnis lainnya. Promosi kesehatan diharapkan dapat meningkatkan pemahaman masyarakat secara umum tentang kesehatan dan secara khusus tentang penanggulangan TB paru. Hal ini karena faktor pengetahuan penderita merupakan salah satu faktor risiko yang paling berpengaruh. Pengetahuan yang kurang tersebut mengenai cara pencegahan dan pemberantasan TB Paru yaitu tidak tahu cara meminun obat, cara mencegah penularan dengan tidak meludah di sembarangan tempat, menjaga kebersihan diri, menutup mulut pada saat batuk dan tindakan lainnya. Pengetahuan penderita yang kurang diduga oleh karena kurangnya informasi menyangkut TB Paru. Keadaan pengetahuan yang kurang seiring dengan sikap penderita yang tidak mau tahu dan akhirnya sangat berpengaruh terhadap tindakan penderita terhadap upaya pencegahan dan pemberantasan (Suryanta, 2016).

Penelitian Sukana (2017) menunjukkan bahwa hampir seluruh penderita TB paru mengetahui tanda dan gejala TB paru $(94,05 \%)$, tetapi sebesar $78,57 \%$ penderita tidak mengetahui 
penyebab TB Paru. Pengetahuan mengenai cara penularan, sebagian besar $(88,09 \%)$ penderita tidak mengetahuinya. Pengetahuan tentang hal yang mempengaruhi penularan TB Paru yang terbanyak tidak tahu $(53,57 \%)$, sedangkan pengetahuan tentang hal-hal yang membantu pengobatan sebagian besar $(60,05 \%)$ sudah mengetahuinya. Sejalan juga dengan penelitian Soejadi (2017) menunjukkan bahwa pengetahuan responden tentang tuberkulosis dan sanitasi perumahan terhadap kejadian tuberkulosis masih sangat rendah, dimana hasil penelitian menggambarkan pengetahuan dengan kategori rendah sebesar 65,9\%, kategori sedang sebesar 27,5\% dan kategori tinggi hanya 6,6\% .

Batuk dari seorang penderita TB Paru dapat memproduksi 3000 droplet nuclei Daya penularan dari seorang penderita TB Paru ditentukan oleh banyaknya kuman yangdikeluarkan dari parunya. Makin tinggi derajat positif hasil pemeriksaan dahak, maka makin menular penyakit penderita tesebut. Jadi, pasien yang menderita TB Paru dengan prilaku yang kurang sehat merupakan salah satu faktor yang mempercepat proses penularan, hal inilah yang merupakan salah satu penyebab sulitnya menurunkan angka penderita TB Paru di Masyarakat . Selain sirkulasi udara, maka pencahayaan di ruang rumah pasien harus di perhatikan. Kuman TB Paru dapat bertahan hidup dalam kegelapan/kelembaban dalam beberapa jam, namun sinar matahari langsung dapat secara cepat membunuhnya (Suryanta, 2016).

Berdasarkan aspek kuratif, diketahui strategi pengobatan bagi penderita TB paru pada masyarakat cenderung belum berorientasi pada penyembuhan secara sempurna, hal ini diindikasikan dari adanya masyarakat positif TB Paru yang drop out dari proses pengobatan dengan persentase sebesar $39,2 \%$, dan tidak adanya upaya monitoring yang evaluatif terhadap sehingga tidak dapat diidentifikasi tingkat cakupan kesembuhan TB Paru pada masyarakat.

Menurut Widjanarko (2016), penemuan kasus TB Paru mengalami peningkatan setiap tahunnya sejak strategi Directly Observed Treatment Short- course (DOTS) digalakkan pada tahun 2015. Penemuan TB Paru dengan BTA positif sebanyak 15,62\% dari 1626 spesimen suspek TB Paru, angka kesembuhan masih $79,75 \%$, dan ditemukan pula putus berobat sebanyak $16 \%$, serta penderita lalai berobat sebanyak 21\%. Dan, hampir semua penderita TB Paru memiliki PMO, dimana PMO tersebut berasal dari keluarga pasien sendiri. Pengetahuan, sikap dan praktik seorang PMO yang buruk akan menyebabkan kegagalan pengobatan TB Paru, karena pengobatan ini memerlukan waktu yang cukup lama. Hal ini disebabkan karena umumnya kuman penyebab TB paru yaitu Mycobacterium tuberculosis bersifat intraseluler.

Penanggulangan TB paru di Masyarakat cenderung belum memberikan kontribusi positif terhadap penurunan angka kesakitan akibat TB Paru, sehingga perlu upaya yang lebih tepat sasaran serta berdaya guna dalam penanggulangan TB paru di Masyarakat, meskipun upaya pelayanan kesehatan untuk pencegahan dan pemberantasan TB Paru sudah dilakukan oleh masyarakat, seperti melakukan pemberian penyuluhan, gerakan kebersihan lingkungan dan pemutaran slide film-film kesehatan dan lainnya yang berhubungan dengan penyuluhan kesehatan serta obat-obat yang dibutuhkan untuk penanggulangan dan pemberantasan TB Paru di Masyarakat (Suryanta, 2016).

Namun dalam kenyataan jumlah kasus TB Paru di Masyarakat masih saja meningkat. Hal tersebut mendeskripsikan bahwa upaya yang telah dilakukan manajemen Masyarakat untuk meningkatkan pengetahuan dan sikap masyarakat dalam menjaga kesehatan pribadinya khususnya dalam pencegahan penyakit menular termasuk TB Paru, namun pada praktenya belum mampu mengubah masalah kesehatan individu Masyarakat, untuk itu perlu dilakukan penelitian tentang upaya promosi kesehatan yang lebih efesien dan efektif dalam peningkatan pengetahuan dan perilaku penghui Masyarakat dalam penanggulangan TB paru di Masyarakat.

Berdasarkan hasil survei dan observasi pendahuluan yang dilakukan peneliti pada bulan Januari 2021, menunjukkan bahwa pada Puskesmas Batu Tunggal Labuhan Batu Utara, terdapat 44 Pasien yang positif TB Paru mayoritas mempunyai perilaku berisiko terhadap penularan TB paru bagi masyarakat lainnya, seperti meludah sembarang tempat, serta perilaku memperparah terjadinya TB paru seperti merokok, serta mempunyai kebiasaan tidur larut malam, promosi tentang penularan TB paru pun sudah sering dilaksanakan tetapi masih kurang di karenakan prilaku masyarakat dan pasien.

\section{METODE PENELITIAN}

JURKESMAS : Jurnal Kesehatan Masyarakat, Vol. 1, No. 1, Juli 2021: 14 - 25 
Penelitian ini dilaksanakan di wilayah kerja Puskesmas Batu Tunggal Labuhan Batu Utara Kecamatan NA IX/X Kabupaten Labuhanbatu yang beralamat di desa Aek Kota Batu. Keadaan wilayah kerja Puskesmas Batu Tunggal berada di pinggir jalan raya, sekitar perumahan warga dengan luas wilayah kerja 428,75 Ha. Puskesmas Batu Tunggal berada pada ketinggian berkisar luas 500 meter diatas permukaan laut. Puskesmas Batu Tunggal termasuk wilayah kecamatan Na IX-X dengan batas wilayah kerjanya sebagai berikut:

Sebelah utara : berbatasan dengan desa Kampung Pajak

Sebelah timur : berbatasan dengan Kecamatan Bilah Barat

Sebelah selatan : berbatasan dengan Tapanuli Utara

Sebelah barat : berbatas dengan kecamatan marbo

Wilayah kerja Puskesmas Puskesmas Batu Tunggal Labuhan Batu Utara Kecamatan NA IX/X Kabupaten Labuhanbatu terdiri dari 8 desa dan 1 kelurahan yaitu Desa Aek Kota Batu, Desa Simpang Marbau, Desa Sei Raja, Kelurahan Silumajang, Desa Pasang Lela, Desa Perk Berangir, Desa Hatapang, Desa Batu Tunggal, Pematang.

\section{HASIL DAN PEMBAHASAN}

\subsection{Hasil}

Berdasarkan hasil penelitian di Puskesmas Batu Tunggal Labuhan Batu Utara Kecamatan NA IX/X Kabupaten Labuhanbatu Utara Tahun 2021 diketahui data karakteristik responden berdasarkan umur, jenis kelamin, tingkat pendidikan, dan pekerjaan yang diperoleh dari 44 responden. Hasil data karakteristik responden disajikan dalam bentuk tabel 1 di bawah ini:

Tabel 1. Data Karakteristik Responden di Puskesmas Batu Tunggal Labuhan Batu Utara Kecamatan NA IX/X Kabupaten Labuhanbatu Utara Tahun 2021

\begin{tabular}{|c|c|c|c|}
\hline No & Data Demografi & Frekuensi & Presentase (\%) \\
\hline \multirow[t]{5}{*}{1} & Umur & & \\
\hline & $20-35$ thn & 5 & 11,4 \\
\hline & $36-50$ thn & 33 & 75,0 \\
\hline & $>50$ thn & 6 & 13,6 \\
\hline & Jumlah & 44 & 100 \\
\hline \multirow[t]{4}{*}{2} & Jenis Kelamin & & \\
\hline & Laki-laki & 31 & 70,5 \\
\hline & Perempuan & 13 & 29,5 \\
\hline & Jumlah & 44 & 100 \\
\hline \multirow[t]{5}{*}{3} & Tingkat Pendidikan & & \\
\hline & Tamat SD & 2 & 4,5 \\
\hline & Tamat SLTP / SLTA & 34 & 77,3 \\
\hline & D-3 / S-1 & 8 & 18,2 \\
\hline & Jumlah & 44 & 100 \\
\hline \multirow[t]{7}{*}{4} & Pekerjaan & & \\
\hline & Petani/Buruh & 7 & 15,9 \\
\hline & Wiraswasta & 15 & 34,1 \\
\hline & Pegawai Swasta & 3 & 6,8 \\
\hline & PNS & 6 & 13,6 \\
\hline & Tidak Bekerja & 13 & 29,5 \\
\hline & Jumlah & 44 & 100 \\
\hline
\end{tabular}

Berdasarkan tabel 1 di atas diketahui karakteristik responden berdasarkan umur mayoritas pasien TB Paru yang menjadi responden rata-rata berumur 36-50 tahun sebanyak 33 orang $(75,0 \%)$, dengan jenis kelamin terbanyak yang menderita TB Paru adalah laki-laki sebanyak 31 orang $(70,5 \%)$ dibandingkan perempuan yang hanya 13 orang $(29,5 \%)$. Jika dilihat dari tingkat pendidikan mayoritas responden adalah tamatan SLTP / SLTA yaitu sebanyak 34 orang (77,3\%), dengan pekerjaan responden terbanyak adalah Wiraswasta sebanyak 15 orang $(34,1 \%)$. 
Perilaku Pencegahan Tuberkulosis Paru sebelum Promosi Kesehatan Di Puskesmas Batu Tunggal Labuhan Batu Utara. Data perilaku pencegahan tuberkulosis paru sebelum promosi kesehatan di Puskesmas Batu Tunggal Labuhan Batu Utara Kecamatan NA 1X/X Kabupaten Labuhanbatu Utara Tahun 2021 dapat dilihat pada tabel 2 di bawah berikut :

Tabel 2. Perilaku Pencegahan Tuberkulosis Paru sebelum Promosi Kesehatan di Puskesmas Batu Tunggal Labuhan Batu Utara Kecamatan NA IX/X Kabupaten Labuhanbatu Utara Tahun 2021

\begin{tabular}{ccc}
\hline $\begin{array}{c}\text { Perilaku Pencegahan } \\
\text { Tuberkulosis Paru (Pre) }\end{array}$ & Frekuensi & \% \\
\hline Baik & 6 & 13,6 \\
Cukup & 27 & 61,4 \\
Kurang & 11 & 25,0 \\
\hline Jumlah & 44 & 100 \\
\hline
\end{tabular}

Berdasarkan tabel 2 di atas menunjukkan bahwa perilaku pencegahan tuberkulosis paru sebelum promosi kesehatan di Puskesmas Batu Tunggal Labuhan Batu Utara mayoritas memiliki perilaku yang cukup yaitu sebanyak 27 responden $(51,4 \%)$ dan minoritas baik yaitu sebanyak 6 responden $(13,6 \%)$.

Perilaku Pencegahan Tuberkulosis Paru sesudah Promosi Kesehatan Di Puskesmas Batu Tunggal Labuhan Batu Utara. Data perilaku pencegahan tuberkulosis paru sesudah promosi kesehatan di Puskesmas Batu Tunggal Labuhan Batu Utara Kecamatan NA 1X/X Kabupaten Labuhanbatu Utara Tahun 2021 dapat dilihat pada tabel 3 di bawah berikut :

Tabel 3. Perilaku Pencegahan Tuberkulosis Paru Sesudah Promosi Kesehatan Di Puskesmas Batu

Tunggal Labuhan Batu Utara Kecamatan NA IX/X Kabupaten Labuhanbatu Utara Tahun 2021

\begin{tabular}{ccc}
\hline $\begin{array}{c}\text { Perilaku Pencegahan } \\
\text { Tuberkulosis Paru (Post) }\end{array}$ & Frekuensi & $\%$ \\
\hline Baik & 23 & 52,3 \\
Cukup & 19 & 43,2 \\
Kurang & 2 & 4,5 \\
\hline Jumlah & 44 & 100 \\
\hline
\end{tabular}

Berdasarkan tabel 3 di atas menunjukkan bahwa perilaku pencegahan tuberkulosis paru sesudah promosi kesehatan di Puskesmas Batu Tunggal Labuhan Batu Utara mayoritas memiliki perilaku yang baik yaitu sebanyak 23 responden $(52,3 \%)$ dan minoritas memiliki perilaku pencegahan tuberkulosis paru yang kurang sebanyak 2 orang $(4,5 \%)$.

Pengobatan Tuberkulosis Paru sebelum Promosi Kesehatan Di Puskesmas Batu Tunggal Labuhan Batu Utara. Data pengobatan tuberkulosis paru sebelum promosi kesehatan di Puskesmas Batu Tunggal Labuhan Batu Utara Kecamatan NA IX/X Kabupaten Labuhanbatu Utara Tahun 2021 dapat dilihat pada tabel 4 di bawah berikut :

Tabel 4. Pengobatan Tuberkulosis Paru Sebelum Promosi Kesehatan Di Puskesmas Batu Tunggal Labuhan Batu Utara Kecamatan NA IX/X Kabupaten Labuhanbatu Utara Tahun 2021

\begin{tabular}{ccc}
\hline Pengobatan & Frekuensi & $\%$ \\
Tuberkulosis Paru (Pre) & 5 & 11,4 \\
Baik & 25 & 56,8 \\
Cukup & 14 & 31,8 \\
\hline Kurang & 44 & 100 \\
\hline
\end{tabular}

Berdasarkan tabel 4 di atas menunjukkan bahwa pengetahuan tentang pengobatan tuberkulosis paru sebelum promosi kesehatan di Puskesmas Batu Tunggal Labuhan Batu Utara mayoritas memiliki pengetahuan pengobatan yang cukup yaitu sebanyak 25 responden $(56,8 \%)$ dan minoritas memiliki pengetahuan pengobatan yang baik sebanyak 5 responden $(11,4 \%)$.

Pengobatan Tuberkulosis Paru sesudah Promosi Kesehatan Di Puskesmas Batu Tunggal Labuhan Batu Utara. Data pengobatan tuberkulosis paru sebelum promosi kesehatan di Puskesmas Batu Tunggal Labuhan Batu Utara Kecamatan NA IX/X Kabupaten Labuhanbatu Utara Tahun 2021 dapat dilihat pada tabel 5 di bawah berikut :

Tabel 5. Pengobatan Tuberkulosis Paru Sebelum Promosi Kesehatan Di Puskesmas Batu Tunggal Labuhan Batu Utara Kecamatan NA IX/X Kabupaten Labuhanbatu Utara Tahun 2021

\begin{tabular}{lcc} 
Pengobatan & Frekuensi & $\%$ \\
\hline
\end{tabular}




\begin{tabular}{ccc}
\hline Tuberkulosis Paru (Post) & & \\
\hline Baik & 13 & 29,5 \\
Cukup & 27 & 61,4 \\
Kurang & 4 & 9,1 \\
\hline Jumlah & 44 & 100
\end{tabular}

Berdasarkan tabel 5 di atas menunjukkan bahwa pengetahuan pengobatan tuberkulosis paru sebelum promosi kesehatan di Puskesmas Batu Tunggal Labuhan Batu Utara mayoritas memiliki pengetahuan pengobatan yang cukup yaitu sebanyak 27 responden $(61,4 \%)$ dan minoritas memiliki pengetahuan pengobatan yang kurang sebanyak 4 responden $(9,1 \%)$.

Pengaruh Promosi Kesehatan Terhadap Perilaku Pencegahan Tuberkulosis Paru Di Puskesmas Batu Tunggal Labuhan Batu Utara. Hasil uji statistik Pengaruh Promosi Kesehatan Terhadap Perilaku Pencegahan Tuberkulosis Paru Di Puskesmas Batu Tunggal Labuhan Batu Utara Kecamatan NA 1X/X Kabupaten Labuhanbatu Utara Tahun 2021 terdapat pada tabel 6 di bawah sebagai berikut :

Tabel 6. Pengaruh Promosi Kesehatan Terhadap Perilaku Pencegahan Tuberkulosis Paru di Puskesmas Batu Tunggal Labuhan Batu Utara Kecamatan NA IX/X Kabupaten Labuhanbatu Utara

Tahun 2021

\begin{tabular}{|c|c|c|c|c|c|}
\hline \multirow{3}{*}{$\begin{array}{c}\text { Perilaku Pencegahan } \\
\text { Tuberkulosis Paru }\end{array}$} & \multicolumn{2}{|c|}{ Promosi Kesehatan } & \multirow[b]{2}{*}{ Perubahan Ranking } & & \multirow{2}{*}{$p$ value } \\
\hline & Sebelum & Sesudah & & & \\
\hline & $\mathbf{F}$ & $\mathbf{F}$ & & $\mathbf{F}$ & \\
\hline $\begin{array}{l}\text { - Baik } \\
\text { - Cukup }\end{array}$ & $\begin{array}{c}6 \\
27\end{array}$ & $\begin{array}{l}23 \\
19\end{array}$ & $\begin{array}{l}\text { Rangking Positif } \\
\text { Rangking Negatif }\end{array}$ & $\begin{array}{c}0 \\
25\end{array}$ & $0,000 *$ \\
\hline - Kurang & 11 & 2 & Ties & 19 & \\
\hline
\end{tabular}

Keterangan Uji Wilcoxon

Perubahan Pengetahuan wanita tentang Pre Menopause:

a. Ranking Negatif adalah perubahan pengetahuan sebelum dan sesudah dari kategori 'kurang' menjadi kategori 'cukup dan baik'

b. Ranking Positif adalah perubahan sebelum dan sesudah dari kategori 'baik' menjadi 'cukup' atau 'kurang'

c. Ties artinya tidak terjadi perubahan pengetahuan sebelum dan sesudah

Berdasarkan tabel 6 di atas menunjukan perilaku pencegahan TB Paru sebelum dan sesudah diberikan promosi kesehatan mengalami peningkatan. Perilaku pencegahan TB Paru sebelum diberikan promosi kesehatan sebanyak 6 pasien masuk dalam kategori baik dan meningkat menjadi 23 responden yang memiliki perilaku yang baik sesudah diberikan promosi kesehatan. Sedangkan sebelum diberikan promosi kesehatan sebanyak 27 responden masuk dalam kategori cukup dan setelah diberikan promosi kesehatan, pasien yang memiliki perilaku yang cukup menurun menjadi 19 responden. Begitu juga dengan pasien yang memiliki perilaku pencegahan yang kurang, pada saat pre tes sebanyak 11 orang memiliki perilaku pencegahan yang kurang dan menurun menjadi 2 orang pada saat post tes.

Berdasarkan Hasil uji statistic dengan menggunakan Uji Wilcoxon diketahui bahwa nilai $\mathrm{p}$ $(0,000)<\alpha(0,05)$ artinya Ho ditolak, jadi terdapat pengaruh yang signifikan promosi kesehatan terhadap perilaku pencegahan Tuberkulosis Paru di Puskesmas Batu Tunggal Labuhan Batu Utara Kecamatan NA IX/X Kabupaten Labuhanbatu Utara Tahun 2021. Hasil ini membuktikan bahwa promosi kesehatan dapat memberikan pengaruh yang positif terhadap peningkatan pencegahan Tuberkulosis Paru di Puskesmas Batu Tunggal Labuhan Batu Utara Kecamatan NA IX/X Kabupaten Labuhanbatu Utara Tahun 2021.

Hasil uji statistik Pengaruh Promosi Kesehatan Terhadap Pengobatan Tuberkulosis Paru di Puskesmas Batu Tunggal Labuhan Batu Utara Kecamatan NA 1X/X Kabupaten Labuhanbatu Utara Tahun 2021 terdapat pada tabel 7 di bawah sebagai berikut :

Tabel 7. Pengaruh Promosi Kesehatan Terhadap Pengobatan Tuberkulosis Paru di Puskesmas Batu Tunggal Labuhan Batu Utara Kecamatan NA IX/X Kabupaten Labuhanbatu Utara Tahun 2021

Promosi Kesehatan Perubahan Ranking p value




\begin{tabular}{lcclcc}
\hline \multicolumn{1}{c}{ Pengobatan } & Sebelum & Sesudah & & & \\
\cline { 2 - 6 } Tuberkulosis Paru & F & F & & F & \\
\hline - Baik & 5 & 13 & Rangking Positif & 0 & $0,000^{*}$ \\
- Cukup & 25 & 27 & Rangking Negatif & 18 & \\
- Kurang & 14 & 4 & Ties & 26 & \\
\hline
\end{tabular}

Keterangan : Uji Wilcoxon

Perubahan perilaku :

a. Ranking Negatif adalah perubahan perilaku sebelum dan sesudah dari kategori 'kurang' menjadi kategori 'cukup' atau 'baik'

b. Ranking Positif adalah perubahan sebelum dan sesudah dari kategori 'baik' menjadi 'cukup' atau 'kurang'

c. Ties artinya tidak terjadi perubahan perilaku sebelum dan sesudah

Berdasarkan tabel 7 di atas menunjukan pengetahuan pengobatan pasien TB Paru sebelum dan sesudah diberikan promosi kesehatan mengalami peningkatan. Pengetahuan pengobatan TB Paru sebelum diberikan promosi kesehatan sebanyak 5 pasien masuk dalam kategori baik dan meningkat menjadi 13 responden yang memiliki perilaku yang baik sesudah diberikan promosi kesehatan. Sedangkan sebelum diberikan promosi kesehatan sebanyak 25 responden masuk dalam kategori cukup dan setelah diberikan promosi kesehatan, pasien yang memiliki perilaku yang cukup meningkat menjadi 27 responden. Begitu juga dengan pasien yang memiliki perilaku pencegahan yang kurang, pada saat pre tes sebanyak 14 orang memiliki perilaku pencegahan yang kurang dan menurun menjadi 4 orang pada saat post tes.

Berdasarkan Hasil uji statistic dengan menggunakan Uji Wilcoxon diketahui bahwa nilai $\mathrm{p}$ $(0,000)<\alpha(0,05)$ artinya Ho ditolak, jadi terdapat pengaruh yang signifikan promosi kesehatan terhadap pengobatan Tuberkulosis Paru di Puskesmas Batu Tunggal Labuhan Batu Utara Kecamatan NA IX/X Kabupaten Labuhanbatu Utara Tahun 2021. Hasil ini membuktikan bahwa promosi kesehatan dapat memberikan pengaruh yang positif terhadap peningkatan pencegahan Tuberkulosis Paru di Puskesmas Batu Tunggal Labuhan Batu Utara Kecamatan NA IX/X Kabupaten Labuhanbatu Utara Tahun 2021.

\subsection{Pembahasan}

A. Perilaku Pencegahan Tuberkulosis Paru sebelum Promosi Kesehatan Di Puskesmas Batu Tunggal Labuhan Batu Utara Kecamatan NA IX/X Kabupaten Labuhanbatu Utara Tahun 2021.

Berdasarkan hasil penelitian menunjukkan bahwa perilaku pencegahan tuberkulosis paru sebelum promosi kesehatan di Puskesmas Batu Tunggal Labuhan Batu Utara mayoritas memiliki perilaku yang cukup yaitu sebanyak 27 responden $(51,4 \%)$ dan minoritas baik yaitu sebanyak 6 responden $(13,6 \%)$.

Berdasarkan hasil kuesioner yang diperoleh bahwa masih tingginya angka penderita TB Paru yang masih melakukan kebiasaan merokok setiap harinya yaitu sekitar 52\%. Hal ini yang masih perlu mendapatkan bimbingan atau promosi kesehatan sehingga penderita TB Paru dapat meninggalkan kebiasaan merokok. Selain itu hampir semua peserta memilih benar pada pernyataan "Pasien Tb dapat menutup hidung dan mulut dengan tangan saat bersin atau batuk". Hal serupa disampaikan penelitian terdahulu (Suharyo \& Mubarokah, 2018). Padahal, etika batuk merupakan salah satu cara untuk memutus rantai penularan TB Paru, terutama dalam keluarga. Etika batuk yang tepat yaitu menutup mulut dan hidung dengan tisu atau masker saat batuk atau bersin, bukan dengan menggunakan tangan. Tisu atau masker yang telah digunakan harus dibuang dan segera melakukan cuci tangan.

Adapun faktor lain di luar faktor promosi yang diberikan misalnya faktor lingkungan di sekitar yang kurang mendukung, faktor motivasi dari diri sendiri, faktor dukungan sosial yang kurang seperti dukungan keluarga, dukungan tenaga kesehatan yang ada di rumah dan beberapa faktor lainnya yang berkaitan dengan tindakan pencegahan.

Hal ini tidak boleh diabaikan, karena beberapa faktor ini juga berperan terhadap tindakan pencegahan, sebagai contoh pengaruh faktor makanan, makanan memiliki peran yang tinggi untuk peningkatan daya tahan tubuh bagi yang belum menderita TB Paru. Jika makanan di rumah disajikan 
dengan memenuhi syarat makanan tinggi kalori dan tinggi protein maka kemungkinan terjadi penularan semakin kecil.

Hal lain yang harus diperhatikan penderita TB Paru dari lingkungan tempat tinggal penderita TB Paru tersebut, yaitu sebaiknya menjaga kebersihan diri dengan mandi 3 kali sehari, menjemur peralatan tempat tidur setiap hari, menghindari kontak yang lama dengan penderita TB Paru dan selalu menggunakan masker. Jadi, kegiatan promosi yang dilakukan harus memperoleh dukungan yang luas, pelaksanaan promosi kesehatan harus disertai dengan melakukan edukasi baik dari petugas kesehatan di puskesmas.

Dalam teori Blum (Notoatmodjo, 2018) menyatakan bahwa pengetahuan atau kognitif merupakan domain yang sangat penting untuk terbentuknya tindakan seseorang. Dalam teori tersebut dijelaskan pula bahwa perilaku merupakan faktor terbesar kedua setelah faktor lingkungan yang mempengaruhi kesehatan individu atau masyarakat, jadi faktor lingkungan merupakan faktor penentu pertama terjadinya perubahan perilaku individu. Oleh sebab itu, dalam rangka membina kesehatan masyarakat, intervensi terhadap faktor perilaku sangat strategis namun harus disejalankan dengan perubahan-perubahan pada kondisi lingkungan sehingga perubahan yang diharapkan dapat terjadi dengan baik.

B. Perilaku Pencegahan Tuberkulosis Paru sesudah Promosi Kesehatan Di Puskesmas Batu Tunggal Labuhan Batu Utara Kecamatan NA IX/X Kabupaten Labuhanbatu Utara Tahun 2021.

Berdasarkan hasil penelitian menunjukkan bahwa perilaku pencegahan tuberkulosis paru sesudah promosi kesehatan di Puskesmas Batu Tunggal Labuhan Batu Utara mayoritas memiliki perilaku yang baik yaitu sebanyak 23 responden $(52,3 \%)$ dan minoritas memiliki perilaku pencegahan tuberkulosis paru yang kurang sebanyak 2 orang $(4,5 \%)$.

Dari hasil ini dapat dilihat bahwa walaupun terdapat peningkatan nilai pada sikap namun jumlahnya tidak terlalu tinggi. Harapan meningkatnya jumlah responden yang memiliki sikap yang kurang baik menjadi baik sebenarnya sangat tinggi jika dilihat nilai peningkatan pengetahuan. Namun demikian ternyata dalam penelitian ini yang masih belum bisa memenuhi sikap responden agar mau bersikap lebih baik dalam melaksanakan pencegahan TB Paru.

Hasil penelitian ini tentunya menggambarkan bahwa intervensi promosi kesehatan yang dilakukan dapat meningkatkan pengetahuan dan sikap responden dalam pencegahan TB Paru, walau akhirnya peningkatan pengetahuan dan sikap tersebut tidak dapat membuat perubahan secara bermakna terhadap tindakan responden dalam pencegahan TB Paru.

Notoadmodjo menyebutkan bahwa sebenarnya perubahan perilaku dapat terjadi jika adanya stimulus yang diberikan dalam bentuk promosi kesehatan. Pelaksanaan promosi secara terus menerus dengan beberapa materi yang terus dikembangkan seiring dengan perkembangan pencegahan dan pengobatan TB Paru dapat mempengaruhi tindakan narapidana dalam mencegah TB Paru.

Perubahan perilaku yang didasari oleh pengetahuan akan lebih baik daripada perilaku yang tidak didasari oleh pengetahuan. WHO juga mengungkapkan bahwa seseorang berperilaku tertentu disebabkan oleh pemikiran dan perasaan dalam bentuk pengetahuan, persepsi, sikap, kepercayaan, dan penilaian-penilaian seseorang terhadap objek. Dalam hal ini, dengan pemberian promosi kesehatan maka pengetahuan akan bertambah sehingga praktik juga akan lebih baik. Hasil penelitian di atas sesuai dengan teori yang dikemukakan oleh Notoatmodjo bahwa seseorang yang bersikap baik akan mewujudkan praktik yang baik dan untuk mewujudkan sikap agar menjadi suatu perbuatan atau tindakan yang nyata diperlukan faktor pendukung atau kondisi.

\section{Pengobatan Tuberkulosis Paru sebelum Promosi Kesehatan Di Puskesmas Batu Tunggal Labuhan Batu Utara Kecamatan NA IX/X Kabupaten Labuhanbatu Utara Tahun 2021.}

Berdasarkan hasil penelitian menunjukkan bahwa pengetahuan tentang pengobatan tuberkulosis paru sebelum promosi kesehatan di Puskesmas Batu Tunggal Labuhan Batu Utara mayoritas memiliki pengetahuan pengobatan yang cukup yaitu sebanyak 25 responden $(56,8 \%)$ dan minoritas memiliki pengetahuan pengobatan yang baik sebanyak 5 responden $(11,4 \%)$. Hal ini terjadi karena sebagian besar responden belum mengetahui sepenuhnya tentang pengobatan tuberkulosis paru dengan benar. 
Untuk meningkatkan pengetahuan penderita TB paru tentang pengobatan TBparu yang intensif dan benar telah dilakukan pemberian informasi (promosi) dengan metode dua arah kepada penderita TB paru, dengan harapan akan terjadi peningkatan pengetahuan penderita TB paru.

Berkaitan dengan hasil penelitian tentang pengetahuan pengobatan TB Paru menunjukkan bahwa perubahan pengetahuan yang diberikan lewat promosi kesehatan diikuti dengan perubahan pengetahuan pengobatan. Dalam penelitian ini ditemukan bahwa responden sangat tahu bahwa agar penyakit TB dapat segera teratasi jika mereka memahami tahapan dalam pengobatan TB Paru secara intensif dan lanjutan.

D. Pengobatan Tuberkulosis Paru sesudah Promosi Kesehatan Di Puskesmas Batu Tunggal Labuhan Batu Utara Kecamatan NA IX/X Kabupaten Labuhanbatu Utara Tahun 2021.

Berdasarkan hasil penelitian menunjukkan bahwa pengetahuan pengobatan tuberkulosis paru sebelum promosi kesehatan di Puskesmas Batu Tunggal Labuhan Batu Utara mayoritas memiliki pengetahuan pengobatan yang cukup yaitu sebanyak 27 responden $(61,4 \%)$ dan minoritas memiliki pengetahuan pengobatan yang kurang sebanyak 4 responden $(9,1 \%)$.

Menurut Notoatmodjo (2012), informasi memberi pengaruh terhadap pengetahuan individu. Meskipun tingkat pendidikannya rendah, jika sering terpapar informasi yang tepat dari berbagai media, maka pengetahuan individu tersebut akan meningkat. Selain itu, mereka juga telah memiliki pengalaman sebelumnya, selama merawat anggota dengan TB Paru. Menurut Kholid (2012), pengalaman merupakan suatu cara untuk memperoleh kebenaran pengetahuan.

Peningkatan pengetahuan pengobatan TB Paru pada responden juga ditunjukkan dari perubahan pengetahuan pengobatan. Dalam penelitian ini ditemukan bahwa responden sangat tahu bahwa agar penyakit TB dapat segera teratasi jika mereka memahami tahapan dalam pengobatan TB Paru secara intensif dan lanjutan.

Promosi kesehatan yang berkaitan dengan penyuluhan pada dasarnya merupakan proses komunikasi dan proses perubahan perilaku melalui pendidikan. Agar kegiatan penyuluhan dapat mencapai hasil yang maksimal, maka metode dan media penyuluhan perlu mendapat perhatian yang besar dan harus disesuaikan dengan sasaran. Penggunaan kombinasi berbagai media akan sangat membantu dalam proses penyuluhan kesehatan. Menurut Edgar Dale dalam Notoatmodjo (2003), semakin banyak indera yang digunakan untuk menerima sesuatu maka semakin banyak dan semakin jelas pula pengertian/pengetahuan yang diperoleh. Penggunaan alat peraga dalam melakukan penyuluhan akan membantu penyampaian pesan kepada seseorang/masyarakat secara lebih jelas dan dapat diterima dengan jelas.

Depkes RI (2012) menitikberatkan bahwa promosi kesehatan bukan hanyasekedar proses penyadaran masyarakat atau pemberian dan peningkatan pengetahuan masyarakat tentang kesehatan saja, tetapi juga disertai upaya-upaya menfasilitasi perubahan perilaku. Oleh karena itu keberhasilan pengobatan TB paru sangat ditentukan oleh adanya keteraturan minum obat antituberkulosis. Hal ini dapat dicapai dengan adanya kesadaran penderita TB paru untuk meminum obat secara teratur melalui upaya peningkatan pengetahuan penderita TB paru tentang pencegahan dan pengobatan TB paru.

\section{E. Pengaruh Promosi Kesehatan Terhadap Perilaku Pencegahan Tuberkulosis Paru Di Puskesmas Batu Tunggal Labuhan Batu Utara Kecamatan NA IX/X Kabupaten Labuhanbatu Utara Tahun 2021.}

Berdasarkan hasil penelitian menunjukan perilaku pencegahan TB Paru sebelum dan sesudah diberikan promosi kesehatan mengalami peningkatan. perilaku pencegahan TB Paru sebelum diberikan promosi kesehatan sebanyak 6 pasien masuk dalam kategori baik dan meningkat menjadi 23 responden yang memiliki perilaku yang baik sesudah diberikan promosi kesehatan. Sedangkan sebelum diberikan promosi kesehatan sebanyak 27 responden masuk dalam kategori cukup dan setelah diberikan promosi kesehatan, pasien yang memiliki perilaku yang cukup menurun menjadi 19 responden. Begitu juga dengan pasien yang memiliki perilaku pencegahan yang kurang, pada saat pre tes sebanyak 11 orang memiliki perilaku pencegahan yang kurang dan menurun menjadi 2 orang pada saat post tes.

Berdasarkan Hasil uji statistic dengan menggunakan Uji Wilcoxon diketahui bahwa nilai $\mathrm{p}$ $(0,000)<\alpha(0,05)$ artinya Ho ditolak, jadi terdapat pengaruh yang signifikan promosi kesehatan 
terhadap perilaku pencegahan Tuberkulosis Paru di Puskesmas Batu Tunggal Labuhan Batu Utara Kecamatan NA IX/X Kabupaten Labuhanbatu Utara Tahun 2021. Hasil ini membuktikan bahwa promosi kesehatan dapat memberikan pengaruh yang positif terhadap peningkatan pencegahan Tuberkulosis Paru di Puskesmas Batu Tunggal Labuhan Batu Utara Kecamatan NA IX/X Kabupaten Labuhanbatu Utara Tahun 2021.

Pengaruh dari metode dan media promosi kesehatan yang digunakan dapat memberikan dampak kepada sipenerima untuk diterima atau ditangkap melalui panca indera, jadi, semakin banyak indera yang digunakan untuk menerima sesuatu maka semakin banyak dan semakin jelas informasi yang disampaikan sehingga informasi dapat dengan mudah dipahami oleh sipenerima.

Menurut (Notoatmodjo, 2018), kemampuan daya serap manusia 2,5\%, melalui pengecapan, $3,5 \%$ melalui perabaan, $1 \%$ melalui penciuman, $11 \%$ melalui pendengaran dan penglihatan $82 \%$. Pemberian informasi dengan menggunakan metode ceramah dan media audiovisual dapat berpengaruh langsung terhadap perubahan pengetahuan dan sikap penderita TB dalam pencegahan TB, dimana hal tersebut dapat memotivasi mereka sehingga berperilaku lebih baik. Peningkatan pengetahuan dan sikap yang baik dari penderita TB setelah mendapat intervensi atau informasi baru melalui audiovisual yang dierima dengan harapan mereka dapat berperilaku lebih baik dalam menjaga, mencegah, menghindari atau mengatasi resiko yang telah terjadi. Pengetahuan diperlukan sebagai dukungan dalam menimbulkan rasa percaya diri maupun sisikap dan perilaku kelompok masyarakat setiap harinya, sehingga dapat dikatakan bahwa pengetahuan merupakan domain yang sangat penting dalam terbentuknya sikap dan tindakan seseorang (Notoadmodjo, 2013).

F. Pengaruh Promosi Kesehatan Terhadap Pengobatan Tuberkulosis Paru di Puskesmas Batu Tunggal Labuhan Batu Utara Kecamatan NA IX/X Kabupaten Labuhanbatu Utara Tahun 2021.

Berdasarkan hasil analisis menunjukan bahwa pengetahuan pengobatan pasien TB Paru sebelum dan sesudah diberikan promosi kesehatan mengalami peningkatan. Pengetahuan pengobatan TB Paru sebelum diberikan promosi kesehatan sebanyak 5 pasien masuk dalam kategori baik dan meningkat menjadi 13 responden yang memiliki perilaku yang baik sesudah diberikan promosi kesehatan. Sedangkan sebelum diberikan promosi kesehatan sebanyak 25 responden masuk dalam kategori cukup dan setelah diberikan promosi kesehatan, pasien yang memiliki perilaku yang cukup meningkat menjadi 27 responden. Begitu juga dengan pasien yang memiliki perilaku pencegahan yang kurang, pada saat pre tes sebanyak 14 orang memiliki perilaku pencegahan yang kurang dan menurun menjadi 4 orang pada saat post tes.

Hasil uji statistic dengan menggunakan Uji Wilcoxon menunjukkan bahwa nilai p $(0,000)<$ $\alpha(0,05)$ artinya Ho ditolak, jadi terdapat pengaruh yang signifikan promosi kesehatan terhadap pengobatan Tuberkulosis Paru di Puskesmas Batu Tunggal Labuhan Batu Utara Kecamatan NA 1X/X Kabupaten Labuhanbatu Utara Tahun 2021. Hasil ini membuktikan bahwa promosi kesehatan dapat memberikan pengaruh yang positif terhadap peningkatan pencegahan Tuberkulosis Paru di Puskesmas Batu Tunggal Labuhan Batu Utara Kecamatan NA 1X/X Kabupaten Labuhanbatu Utara Tahun 2021.

Pengetahuan akan upaya pencegahan penyakit TB bisa didapatkan dari berbagai sumber seperti media masa, media elektronik, serta penyuluhan dan pendidikan kesehatan. Salah satu metode untuk memberikan Pendidikan kesehatan adalah dengan menggunakan metode ceramah dan media audiovisual/film, media audiovisual dapat menyampaikan pesan melalui alat bantu yang digunakan untuk memberikan informasi kesehatan kepada masyarakat maupun kelompok (Notoatmodjo, 2018). Peningkatan minat terhadap media pembelajaran audiovisual tentunya lebih besar dari pada media proyeksi, hal ini disebabkan karena Audiovisual dapat menampilkan gambar yang bergerak sehingga minat dan keinginan responden untuk mengikuti pendidikan kesehatan semakin tinggi. Keinginan responden dalam mengikuti pendidikan kesehatan akan mempengaruhi pengetahuan dan sikap mereka, (Azwar, 2013) menyatakan semakin tinggi minat responden dalam mengikuti penyuluhan kesehatan akan berdampak pada peningkatan pengetahuan responden tentang pencegahan penyakit TB, sehingga akan terbentuk sikap yang baik dalam upaya pencegahan penyakit TB. 
Promosi kesehatan perlu dilakukan secara rutin dan teratur dengan menggunakan metode dan media yang lebih menarik sehingga orang lain atau masyarakat dapat dengan mudah memahami apa yang disampaikan kepada mereka.

\section{KESIMPULAN}

Perilaku pencegahan tuberkulosis paru sebelum promosi kesehatan di Puskesmas Batu Tunggal Labuhan Batu Utara mayoritas memiliki perilaku yang cukup yaitu sebanyak 27, Perilaku pencegahan tuberkulosis paru sesudah promosi kesehatan di Puskesmas Batu Tunggal Labuhan Batu Utara mayoritas memiliki perilaku yang baik yaitu sebanyak 23, Pengetahuan pengobatan tuberkulosis paru sebelum promosi kesehatan di Puskesmas Batu Tunggal Labuhan Batu Utara mayoritas memiliki pengetahuan pengobatan yang cukup yaitu sebanyak 27 responden, Terdapat pengaruh yang signifikan antara promosi kesehatan terhadap perilaku pencegahan Tuberkulosis Paru di Puskesmas Batu Tunggal Labuhan Batu Utara Kecamatan NA 1X/X Kabupaten Labuhanbatu Utara Tahun 2021, dengan nilai p $(0,000)<\alpha(0,05)$. Hasil ini membuktikan bahwa promosi kesehatan dapat memberikan pengaruh yang positif terhadap peningkatan pencegahan Tuberkulosis Paru di Puskesmas Batu Tunggal Labuhan Batu Utara Kecamatan NA IX/X Kabupaten Labuhanbatu Utara Tahun 2021, Terdapat pengaruh yang signifikan antara promosi kesehatan terhadap pengoatan Tuberkulosis Paru di Puskesmas Batu Tunggal Labuhan Batu Utara Kecamatan NA IX/X Kabupaten Labuhanbatu Utara Tahun 2021, dengan nilai $\mathrm{p}(0,000)<\alpha(0,05)$. Hasil ini membuktikan bahwa promosi kesehatan dapat memberikan pengaruh yang positif terhadap peningkatan pengetahuan tentang pengobatan Tuberkulosis Paru di Puskesmas Batu Tunggal Labuhan Batu Utara Kecamatan NA IX/X Kabupaten Labuhanbatu Utara Tahun 2021.

\section{REFERENSI}

Crofton, S.J., Horne, N., dan Miller,f. 2017 . Clinical Tuberkulosis. Jakarta: Widya Medika

Departemen Kesehatan RI. 2017 . Petunjuk Pengunaan Obat Anti Tuberkulosis Fixed Dose Combination ( OAD_FDC ). Jakarta; DepKes RI

2017. Promosi Kesehatan dalam Era Desentralisasi. Pusat Promosi Kesehatan. Jakarta

2018. Pedoman Nasional Penangulangan Tuberkulosis. Jakarta

2016. Pedoman Nasional Penanggulangan Tuberkulosis. Edisi 2. Cetakan Pertama. Jakarta

2019. Undang-Undang Nomor 36 Tahun 2009 Tentang Kesehatan Balitbangkes. Jakarta:

Kementerian Kesehatan RI

Dick, G. 2015 . Imunisasi dalam Praktek. Alih Bahasa : Petrus Andrianto, Hipokrates. Jakarta

Ewles, Linda dan Ina Simnett. 2015 . Promosi Kesehatan, Petunjuk Praktis Edisi Kedua. Yogyakarta: Gadjah Mada University Press

Gegia, Medea. 2018. Developing A Human Rights-Based Program For Tuberculosis Control In Georgian Prisons. Health and Human Rights: Vol. 13, No. 2, December 2011.

Green, Lawrence W., Marshall W. Kreuter. 2015. Health Promotion Planning; An Educational and Environmental Approach. London: Mayfield Publishing Company

2015. Health Program Planning An Educational And Ecological Approach:

Fourth Edition: ISBN 007255683.8. Published By Mc-Graw- Hill, 1121 Avenue of The Americas. New York.

Helper. 2011. Aspek Pengetahuan Sikap dan Perilaku Masyarakat Kaitannya dengan Penyakit TB Paru. Jakarta : Media Litbang Kesehatan Volume 21.

Hidayat, Dede Rahmat. 2019. Ilmu Perilaku Manusia. Jakarta: CV Trans Info Media

Kementerian Kesehatan REPUBLIK INDONESIA, Direktorat Jenderal Pengendalian Penyakit dan Penyehatan Lingkungan. 2011, Strategi Nasional Pengendalian TB di Indonesia 2010-2014. Jakarta

Liliweri. A., 2017. Dasar - Dasar Komunikasi Kesehatan. Kupang: Pustaka Pelajar

Manzoor.S, 2019. Prevalence of HIV and Tuberculosis Among Jail Inmates In Lahore - Pakistan. Departments Of Bacteriology And Environmental Health, Institute Of Public Health, Lahore, Journal Biomedica Vol. 2,5 P.36-41 
Ospina. 2012. Community Health Workers Improve Contact Tracing Among Immigrants with Tuberculosis in Barcelona. Article: Public Health

Paul. 2020. Tuberculosis Knowledge, Attitudes, and Beliefs in Foreign-born and US-born Patients with Latent Tuberculosis Infection. USA: Springer Science+Business Media, LLC.

Price A,S. 2015. Penyakit Tuberkulosis Paru. Jakarta: EGC

Roy,A. 2018, Evaluating Knowledge Gain from TB Leaflets for Prison and Homeless Sector Staff: The National Knowledge Service TB Pilot. Oxford University Press, European Journal of Public Health, Vol.18, No.6, 600-603.

Rusnoto, P. Faktor-Faktor yang Berhubungan dengan Kejadian TB Paru pada Usia Dewasa (Studi Kasusdi Balai Pencegahan dan Pengobatan Penyakit Paru Pati). Semarang: Universitas Diponegoro

Towle, A. 2016. Doctor-patient communications in the Aboriginal community: towards the development of educational programs. Patient Educ Couns Tuberkulosis Coalition for Technical Assistance, International Standard for Tuberkulosis Care(ISTC), The Hague. 2006 Saifuddin. 2008. Sikap Manusia Teori dan Pengukurannya (Edisi ke 3). Yogyakarta: Pustaka Pelajar

Sarwono, S. 2017. Sosiologi Kesehatan; Beberapa Konsep Beserta Aplikasinya. Yogyakarta: Gadjah Mada University Press

Soejadi, Teddy Bambang, Desy Ari Apsari, Suprapto. 2007. Analisis Faktor- Faktor Yang Mempengaruhi Kejadian Kasus Tuberculosis Paru. Jurnal Ilmiah Pannmed, Vol. 2, No. 1, Juli 2017

Sukana. 2019. Pengaruh Penyuluhan Terhadap Pengetahuan Penderita TB Paru di Kabupaten Tangerang. Jurnal Ekologi Kesehatan Vol. 2, No. 3, Desember 2020

Volmink J, Matchaba P, Garner P. 2000. Directly Observed Therapy and Treatment Adherence. Lancet.

WHO. 2018. Treatment of Tuberkulosis: Guidelines for National Programmes, 3rd edition, Genev 